\title{
Non-retroactivity in Prosecuting Crimes against Humanity and International Crimes Tribunal Bangladesh
}

\author{
Maruf Billah ${ }^{1}$ \\ ${ }^{1}$ Graduate School of International Development, Nagoya University, Nagoya, Japan \\ Correspondence: Maruf Billah, Graduate School of International Development, Nagoya University, Nagoya, Furo- \\ Cho, Chikusa-Ku, Nagoya 464-8601, Japan. E-mail: billah.maruf@g.mbox.nagoya-u.ac.jp; \\ marufiium@gmail.com
}

Received: July 18, 2020

doi:10.5539/jpl.v13n3p180
Accepted: August 10, $2020 \quad$ Online Published: August 30, 2020

URL: https://doi.org/10.5539/jpl.v13n3p180

\begin{abstract}
The International Crimes Tribunal Bangladesh (ICTB) was set up by Bangladesh through the adaptation of the International Crimes Tribunal Act 1973, as an internal mechanism trying to prosecute and punish Bangladeshi perpetrators who committed international crimes in Bangladesh liberation war in 1971. After a long disappearance from the public eye, the Tribunal was reemerged in 2010 . The recent cases decided by the Tribunal have revealed that the international crimes; namely, crimes against humanity, were allegedly committed in 1971, while the relevant Statute was enacted in 1973, and was implemented in 2010. Recently, the ICTB is prosecuting crimes against humanity retroactively, which might have violated the prohibition of penalizing certain conducts committed by the perpetrators before the enforcement of such conduct as a law banning such demeanor as an offense. Therefore, this study firstly analyzes the rule against retroactivity in international criminal law. Secondly, it investigates the justification of the retroactive criminalization of crimes against humanity at the first International Military Tribunal, Nuremberg, and its crystallization into the regional and international legal instruments. Thirdly, the study examines the characteristics of crimes against humanity as an international crime, to scrutinize whether the ICTB needs to fulfill such requirements either in 1971 or 2010. Then, it illustrates various judgments of the ICTB, demonstrating that it does not comply with the rule prescribed by international laws either in 1971 or 2010 , in prosecuting crimes against humanity retroactively. Lastly, the study concludes by forwarding ways necessary to the ICTB in retroactive prosecution of international offenses.
\end{abstract}

Keywords: non-retroactivity, crimes against humanity, international crimes tribunal Bangladesh

\section{Introduction}

The ICTB was commenced through the enactment of the International Crimes Tribunal (ICT) Act 1973 by the Bangladesh Legislative Assembly after the Liberation Conflict of 1971, in which the Eastern part separated from the Western part of the then Pakistan to form the currently sovereign State of Bangladesh. During the nine-month War of Independence, the then East Pakistanis saw a military crackdown by the West Pakistani forces, leading to a civil war with persecution and mass killings. It caused an overwhelming number of deaths, displacements, and acts of sexual violence (Sen, 2012). That resulted in the creating of the Tribunal to prosecute and punish the West Pakistani forces and their local collaborators of Bangladeshi origin who opposed the Liberation War of Bangladesh. However, due to political instability among India, Pakistan, and newly independent Bangladesh States, it was not possible to instigate any process of bringing the Pakistani perpetrators before justice.

Consequently, after a long disappearance from the public eye, the ICT Act 1973 reemerged in 2009, and the ICTB commenced in 2010 to bring the offenders of the 1971 conflict those were accountable for perpetrating international crimes; such as genocide, crimes against humanity, crimes of aggression, and war crimes. The international community welcomed the establishment of the ICTB as a domestic criminal tribunal created under the authority of the sovereign Bangladesh government. The ICT Act 1973 enacted and enforced on 20 July 1973, was signified it as one of the first tribunals in South Asia in ending the past impunity for international crimes since the International Military Tribunal Nuremberg (hereinafter "IMT") of the 1940s (Menon, 2017). It is also proved the required strategic demonstration of Bangladesh's will to ensure criminal justice for the victims of the 1971 conflict.

The ICTB is authorized to prosecute international offenses retroactively. Section 3 (1) of the ICT Act 1973 (Note 
1) has sanctioned in prosecuting crimes perpetrated before or after the commencement of the Legislation-20 July 1973. The word 'before' means the Act 1973 has the power to prosecute offenses that are committed before the initiation date of this legislation. Therefore, the heinous acts perpetrated in the path of the liberation war of Bangladesh, which started on 25 March and ended up on 16 December 1971, can be prosecuted under this Act. Then, the word 'after' merely includes offenses committed after 1973 can also be tried before the Tribunal. To date, the ICTB is only prosecuting internationally recognized crimes retroactively, which were perpetrated in 1971 (Note 2). In the ICTB, most of the offenders have been accused of crimes against humanity in connection with any other international crimes such as genocide and violation of any humanitarian rules applicable in armed conflicts under the Geneva Conventions 1949. This study, therefore, only analyzes retrospective prosecution of crimes against humanity under the ICTB according to the principle of non-retroactivity.

Section 3 (2) (a) the ICT Act 1973 spells out the definition of crimes against humanity like the first type of international offense:

"CRIMES AGAINST HUMANITY: namely, murder, extermination, enslavement, deportation, imprisonment, abduction, confinement, torture, rape ... committed against any civilian population or persecutions on political, racial, ethnic or religious grounds, whether or not in violation of the domestic ... where perpetrated."

The notion of crimes against humanity in the ICTB was borrowed from the concept of the IMT Charter. The IMT was the first international criminal Tribunal that took place in 1945 to prosecute crimes against humanity committed in the World War (WW) II. It was similar to the ICTB, in which designated crimes were committed during an international armed conflict in 1971. Crimes against humanity undoubtedly emerged as the new in the ICTB material jurisdiction introduced in 1973, a retroactive crime after the heinous event took place in 1971. Hence, the ICTB is permitted to try and punish offenders of crimes against humanity even though similar crimes were not existent at the appropriate time. The Tribunal observes, "[e]ven under retrospective Legislation (Act enacted in 1973) initiation to prosecute crimes against humanity ... committed in violation of customary international law is quite permitted (Prosecutor v. Delowar Hossain Sayeedi, 2013, para. 52)." In most of the cases, the Tribunal also submitted that "[i]t is to be noted that the ICTY, ICTR, and SCSL [Special Court for Sierra Leone] the judicial bodies backed by the UN have been constituted under their respective retrospective Statutes (Prosecutor v. Abul Kalam Azad, para. 14)," (Note 3). All of the arguments are given in the verdicts of the ICTB put a question on whether the rules of retrospectivity need to comply with the customary international law of 1971 (i.e., offenses need to be committed in an interstate armed conflict), the time of the commission of the perpetrated crimes or not. The ICTB only analyzed the admissibility of the retrospective law in the material jurisdiction of the Tribunal.

Hence, the above-mentioned legal quotations of the ICTB are considered as the central analytical points to the current discussion, which means that crimes against humanity and other international crimes can be prosecuted before the ICTB even under retrospective law. Therefore, some critical issues need consideration in the current discussion. First, it is relevant to analyze the general rule on the prohibition of retrospective proceedings of crimes against humanity in international law. Whether international law always bans retrospective prosecutions of such crimes? If it is not forbidden, then the second issue comes forward whether the ICTB has any legal justification for taking lawful action against the offenders of crimes against humanity based on the Nuremberg ruling. If yes, then the last question needs to answer on what are the characteristics that need to be fulfilled in the retroactive prosecution of crimes against humanity, based on the Nuremberg principle and contemporary international criminal law? Therefore, this study sufficiently justifies an in-depth legal analysis on responding to these questions by reference to international criminal laws and jurisprudence.

\section{A Rule to Prohibit Retroactive Prosecution of Crimes against Humanity in Customary International Law}

The well-known Latin maxim "nullum crimen sine lege" (no crime without law) means any demeanor must be criminalized in advance of any criminal tribunal taking place. Since the ICTB is trying to prosecute international crimes retroactively in the domestic courts; hence it is inevitable to ask whether the "nullum crimen" principle is prohibited in the national and international law. As a domestic law, this principle had roots in the Western legal systems since the $18^{\text {th }}$ Century as it was first duly inserted in Article 8 of the French Declaration of the Rights of Man of 1789 (Williams, 1961), by stating, "[n]o one can be punished but under a law established and promulgated before the offense and legally applied." The similar principle also reemerged in Article 8 of the French Constitution of 1791, and it remained in the French Penal Code of 1791, with its successive undertaking in Article 1 of the German Penal Code of 1871 and reformulation in the Weimar Constitution (Popple, 1989). The ban against "ex post facto" laws was also envisaged in Article 1 of the US Constitution (Edinger, 1995). This legal rule was entirely 
acknowledged in Europe and America before the starting of the $20^{\text {th }}$ Century. Later it was followed by almost all constitutions of the civilized nations. Bangladesh also inserted the "nullum crimen" principle in its Constitution (Note 4). So, it is evident that as the domestic legal rule, the "nullum crimen" principle was recognized since the $18^{\text {th }}$ Century.

In the pre-UN era, the "nullum crimen" principle first time appeared at the Paris Peace Conference in 1919 (Note 5). After WW II, the ruling of non-retroactivity in criminalizing offenses was considered as the issue of the customary rule of international legal order applicable equally for domestic and international adjudicating bodies (Gallant, 2009). It was supported by the international legal instrument by stating, "[n]o one shall be accused or convicted of a criminal offense on account of any act or omission which did not constitute a criminal offense under national or international law to which he was subject ... when it was committed," (Note 6). Since Nuremberg, the "nullum crimen" was acknowledged by all of the leading human rights conventions worldwide as one of the nonderogable norms common to all of these international instruments (Note 7).

Therefore, the rule of non-retroactivity can be considered as the "peremptory norm" of international penal law as recently envisaged in the jurisprudence of the Special Tribunal for Lebanon (Prosecutor v. Salim Jamil Ayyash et al. 2011, para 76). There are several rationales available behind the principle of non-retroactivity, such as preserving authority to criminalize any conduct, providing fair notice by allowing ascertaining the prohibited conduct, and daunting the capricious legal proceeding or detention (Robinson, 2005). A retroactive application of criminal law is always prohibited because it protects individuals against the whimsical decisions of the authorities, undoubtedly credits to the expansion of international criminal law (Valentina, 2011). So, it is quite clear that in domestic and international law, the prohibition of retrospective prosecution of international crimes is established as a customary rule since long ago, even sometimes it is considered as the "jus cogens" norm in international criminal law.

Although a retrospective trial is arbitrary, such a prosecution is generally allowed when it will necessarily be justified based on the public policy (Edinger, 1995). A criminal act is seriously harming society should be deterred even retroactively as the ethical value requires it. One of the established examples is crimes against humanity that cannot go unpunished in any means, which was prosecuted at the IMT retroactively, analyzes subsequently.

\section{Retrospective Prosecution of Crimes against Humanity in the IMT Nuremberg}

Though the ICTB is used the concept of crimes against humanity as enshrined in the IMT, it never explained the legal or moral rationales. Hence, it is indispensable to ascertain the meaning of specific crimes concerned by the IMT Charter. Article 6(c) of the IMT Charter reads:

"CRIMES AGAINST HUMANITY: namely, murder, extermination, enslavement, deportation ... committed against any civilian population, before or during the war; or persecutions on political ... in connection with any crime within the jurisdiction of the Tribunal, whether or not in violation of the domestic law of the country where perpetrated."

In the IMT, defendants severely objected to the retroactive criminalization of international crimes. According to one of the earlier scholars, "[t]he Nuremberg trials was severely criticized for providing for punishment of all crimes against humanity, and for declaring the waging of a war of aggression ... steps were said to go beyond existing international law at that time (Williams 1961)." A similar remark was also confirmed by Scholar Clarke (2003), who argues, "Nuremberg Charter was retrospective in operation as the [international crimes] which were the subject of their prosecution were not considered criminal at the time they were committed." Another scholar contends:

"[D]espite protestation that crimes listed in the Charter were existing criminal prohibitions prior to that time, [the London Agreement] created new categories of international crimes: 'crimes against humanity' and 'crimes against peace,' in addition to existing ones ('war crimes') (Mettraux 2010)."

Through the IMT, defense counsel, therefore, disputed that the adjudication should not advance as the ex post facto penalty is repugnant to the law of the civilized country (International Military Tribunal Nuremberg, 1946, 1946, p. 172).

Conversely, in the Nuremberg, judges grounded the criminalization of the whole conducts of the defendants by arguing that those (illegal acts) were perpetrated in the subsistence of an international ruling, irrespective of the missing of any subsequent provision in the municipal law (IMT Nuremberg, 1946, pp. 217-220). Therefore, the London Agreement was the expression of international legal order presented at the moment it formulated (IMT Judgment, 1946, p.461) that was duly accepted by the victorious Allies in WW II. The IMT Judgment further says: 
"To assert that it is unjust to punish those who in defiance of treaties and assurances attacked neighboring states [is] obviously untrue. [T] he attacker must know that he is doing wrong. [I]t would be unjust if his wrong were allowed to go unpunished (IMT Nuremberg, 1946, p. 291)," (Note 8).

By this interpretation, it is clarified that existing agreements, including the Kellogg-Briand Pact (Note 9), and various mutual treaties of neutrality and non-aggression, outlawed the acts of aggression perpetrated by Germany, where defendants' action was undeniably offensive and so punishable (Schaack, 2008).

In resolving the above differences of opinion, it is generally acceptable in all criminal cases that the crime must be the subject of some prior positive law (Dubler \& Kalyk, 2018). Likewise, German lawyers call for an obvious lex that set up a criminal sanction for such an illegal act; without such law, individuals cannot be held liable (Burchard, 2006). Hence, Bassiouni argues "the principle of legality" refers to no crime unless established by law, no penalty without law, and no criminal law with ex post facto effect was indeed codified in the German Criminal Code of 1871 (Bassiouni,1992). Similarly, Jescheck criticizes the Nuremberg Trial for, contrary to prevailing legal opinion, having a "relaxed attitude" to the "nullum crimen" principle that justified the conviction of Streicher, for the persecution of Jews as crimes against humanity irrespective of any prior notice to the local law (Jescheck, 2004). Therefore, it is tough to agree on the proposition that retroactive prosecution of crimes against humanity sufficiently established its lawful ground by the IMT judgment. However, the following discussion highlights the justification of the retrospective adjudication of crimes against humanity by the IMT other than legal grounds.

\section{Justification of Retrospective Prosecution of Crimes against Humanity by the IMT}

The above discussion has clarified that crimes against humanity were retrospectively prosecuted in the IMT, which was not established as the legal principle at that time. However, such prosecution was justified later in international law by the positive interpretation of many scholars and promulgation of such rules into global and regional legal instruments. Therefore, it is essential to scrutinize why and how it was codified?

Firstly, based on the morality principle, scholars have agreed on the legalization of ex post facto criminalization of crimes against humanity at the Nuremberg Tribunal. Though retrospective prosecution was legally not justified, it was established by moral ground to deter the wrongdoers from being committed to international crimes. Kelsen (1947) rightly mentions:

"[I]nternationally illegal acts for which the London Agreement established individual criminal responsibility ... [were] also morally most objectionable, and [those who] committed these acts were certainly aware of their immoral character, [and thus] the retroactivity of the law applied to them can hardly be considered as absolutely incompatible with justice."

Hence, it is rational to regard that the judicial conduct of the IMT was legalized by claiming that the acts of the Nazis were so morally wrong and needed to be penalized accordingly (Popple, 1989). Professor Kelsen reiterates his exceeding view on supporting the retrospective trial of international crimes at the IMT by inferring that though under existing laws, the defendants' acts were not criminal, it was against the moral values and deserved punishment (Note 10). So, it is quite clear that the IMT judgment was accepted on the ground of morality rather than legality to deter future criminals from being committed any conducts that violate human rights at a massive scale.

Secondly, it was gained the rank of the customary international law through a gradual crystallization of such moral principles into the legal one by some chronological adaptations. As the initial promulgation, the IMT Charter was affirmed by the General Assembly of the UN on 11 December 1946 (Note 11). As Dubler and Kalyk comment, within the "principle of international law," stated in the UN General Assembly resolution, the meaning of crimes against humanity mentioned in Article 6(c) of the IMT Charter can be included (Dubler \& Kalyk, 2018). Thus, many scholars of international law depend on this resolution to ascertain that, no less than after December 1946, Article 6(c) of the IMT Charter entered into customary international law (Ibid.). Correspondingly, Brownlie thinks, whatsoever the status of the legislation would have been in 1945, Article 6(c) of the IMT Charter has entered to present general international law (Brownlie, 1990). Then, Professor Cassese considers, once the UN General Assembly affirmed it in 1946, as the "Nuremberg Principle," Article 6(c) was recognized as the customary rule in international law (Cassese, 2006). Some scholars think that the UN General Assembly's pronouncements on the global law characteristics of crimes against humanity were regarded as authoritative (Matas \& Charendoff, 1987). The same view was concluded by the International Law Commission (ILC) in its Nuremberg Principle in 1950 and the ILC Special Rapporteur in 1951 (Note 12).

Then, this moral principle was incorporated as a legal norm in the European Convention on Human Rights (ECHR), the first regional human rights agreement in 1953. Article 7 (2) of the ECHR adequately ensures that any act which 
is not wrongful according to a treaty or custom may nonetheless be held criminal and need to be punished by "the general principles of law recognized by civilized nations." Afterward, this principle was also adopted by the International Covenant on Civil and Political Rights (ICCPR), as the UN multilateral human rights agreement, in 1966. Article 15 (2) of the ICCPR incorporated the principle enshrined by the ECHR, which evidenced that both of these legal incorporations have been considered as the promising legal principles in global penal law. So, it has elucidated that both of the above statutory provisions indeed clearly facilitate the retroactive penalization of conducts regarded unlawful in general international law (Joseph \& Castan, 2000). Here the phrases "general principle of the law" in Article 15(2) of the ICCPR refers to customary international law (Matas \& Charendoff, 1987).

Lastly, a UN ad hoc tribunal, the International Criminal Tribunal for the Former Yugoslavia (ICTY), too adequately adopted the IMT principle of the retrospective trial of crimes against humanity. The Legislation of the ICTY criminalized offenses committed between 1991 and 1993. It is noticeable that the ICTY preserves the authority to adjudicate crimes against humanity and other international crimes committed since 1991(ICTY Statute 1993, Arts. 2-5). The Resolution 827 of the UN Security Council approved the formation of the ICTY, merely in 1993; hence, it might be contended that the ICTY Statute was enforced retrospectively to offenses committed between 1991 and 1993 (Valentina, 2011). Article 1 of the ICTY Legislation authorizes in prosecuting offenders liable for grave breaches of international humanitarian law perpetrated in the former Yugoslavia since 1991 according to the provisions of the ICTY Statute. One of the provisions of this Statute is Article 5 that authorizes crimes against humanity to be prosecuted. The moral principle of the IMT was applied in the ICTY in prosecuting crimes against humanity retrospectively, and it has gradually been adopted as the customary international rule in the later international criminal law and Tribunals. Therefore, the UN Secretary-General in 1993 rightly contended, "Article 6(c) of the IMT Nuremberg Charter has "beyond doubt become parts of customary international law" (Report of the Secretary-General, 1993). Therefore, it is established here that retrospective criminalization of crimes against humanity was justified based on the principle of morality at the IMT and has continuously transformed into many international and regional legal instruments and finally gained the customary law status.

\section{Characteristics of Crimes against Humanity as an International Crime}

In prosecuting crimes against humanity retroactively, some unique characteristics of such crimes need to be considered that developed through the IMT's jurisprudence and were crystallized into international criminal law. The ICTB is adjudicating crimes against humanity committed in 1971 atrocities when the IMT was the only Tribunal that successfully sued the same crimes in international law. So, the subsequent discussion analyzes the essential elements of crimes against humanity in 1971 and contemporary international criminal law.

\subsection{The Connection of "International Armed Conflict" with Crimes against Humanity}

One of the essentials of crimes against humanity that differentiates it from regular crimes is a need to commit in a "war" or "armed conflict." It means any killing types of offenses namely; murder, extermination, and torture need to engage in connection with "war" whether "before or during the war," or persecution types of offenses need to perpetrate in the completion of or in linkage with crimes of aggression or war crimes as stated in the IMT. The phrase "before or during the war" in the original text of the IMT Charter means the atrocities committed prior to the outbreak of the war also amounted to the crimes against humanity. However, it is not the reality of the IMT jurisprudence, hence the Tribunal held:

\footnotetext{
"The Tribunal ... cannot make a general declaration that the acts before 1939 were Crimes against Humanity within the meaning of the Charter, but from the beginning of the war in 1939 War Crimes were committed on a vast scale, which were also Crimes against Humanity; and insofar as the inhumane acts ... committed after the beginning of the war did not constitute War Crimes, they were all committed in execution of, or in connection with, the aggressive war, and therefore constituted Crimes against Humanity (Trials of the Mejor War Criminals, p. 249)."
}

The IMT explained clearly that before the outbreak of the war, the relevant crimes though committed with other international crimes, were not proved satisfactorily as an international crime. After the initiation of the war, crimes against humanity were perpetrated on a large scale in connection with other crimes. Thus, the IMT Judgment sufficiently demonstrated that the material crimes were committed during an international armed conflict.

Accordingly, the nexus of "international armed conflict" was regarded as the jurisdictional requirement of crimes against humanity, the IMT Charter introduced. The ICTB always disregards to comply with this element in prosecuting the specific crimes, though the IMT requirement of crimes against humanity is considered as the analogous elements of the ICTB. One of the reasons is that the relevant atrocities subjected to the ICTB were 
committed in the international armed conflict in 1971. Therefore, to link between the commission of crimes against humanity and "international armed conflict" is crucial to this study due to the following grounds.

First of all, the required nexus of the crimes against humanity with crimes of aggression, and war crimes sufficiently was connected to "international armed conflict" to limit the jurisdictional sphere of crimes against humanity. One of the early scholars Schwelb stated that the theory of a crime against humanity was intimately linked either with war crimes or crimes against peace in the narrower perspective (Schwelb, 1946). Almost similar views corresponded by the scholars in the later period. Professor Bassiouni believes, "crimes against humanity are analogous to war crimes and are an extension thereof, that have long existed and that are the underpinning of laws, norms, and rules of the humanization and regulation of armed conflicts (Bassiouni, 1999)." Therefore, it is rational to articulate that crimes against humanity were indicted in the IMT as the new category of a crime connected to the rules and traditions of war and acts of aggression.

Secondly, to dismiss the connection of an "international armed conflict" as the jurisdictional prerequisite of crimes against humanity is to misinterpret the discussion at the London Agreement of 8 August 1945. As Dubler and Kalyk argue, despite being an ad hoc requirement, the nexus of "international armed conflict" was a very deliberate limit on crimes against humanity over the ordinary crimes committed (Dubler \& Kalyk, 2018). Without such a limitation, any broad authorization to prosecute crimes against humanity would have run the real risk of undermining the seriousness of offenses committed by the Nazi Officials. As Professor Bassiouni again mentions, "[a]t the time the [IMT] Charter was enacted, the war connecting element was indispensable to link "crimes against humanity' to pre-existing conventional and customary international law prohibiting such conduct in time of war (Bassiouni, 1999)."

Finally, for the customary law position of crimes against humanity, enshrined in Article 6(c) of the IMT Charter, generally acknowledged by the UN General Assembly Resolution 95(1) in 1946, which means the nexus of "international armed conflict" was also indisputably accepted. It is inferred; therefore, in any case, the IMT ruling was regarded as customary international law, as the large numbers of states now have stopped denying that the substantive aspects of the IMT Charter and judgment have become part of the positive law (Brownlie, 1990). Thus, it is proved that the connection of crimes against humanity with an "international armed conflict" as an ad hoc jurisdictional condition unique to the moment, sufficiently attained the status of a ruling of international law (Dubler \& Kalyk, 2018)."

\subsection{Abandonment of the Nexus of "International Armed Conflict" from Crimes against Humanity}

Since Nuremberg, the relevancy of the above condition in the jurisdiction of crimes against humanity was debated in international law because nowadays, the characteristics of "armed conflicts" have changed. In this case, two issues need to be considered.

First, the nexus of "international armed conflicts" with crimes against humanity was required during the crime's infancy. Bassiouni observes that a connection with "international armed conflicts" was necessary at the time of the Nuremberg (Bassiouni, 1999). However, this proposition has started declining gradually, due to the Cold War, and it continued until 1993, in response to heinous Yugoslavia's "ethnic cleansing" (Hirad, 2013). As the partial abolishment of the nexus requirement, Article 5 of the ICTY Statute (Note 13) in 1993 was drafted based on Article 6(c) of the IMT Charter, requiring the crimes in question have to be perpetrated either in international or internal armed conflict. However, the nexus of "international armed conflicts," as the jurisdiction of the crimes against humanity, was entirely discarded in 1995 by the Chamber of Appeals of the ICTY in its Tadić case (Note 14).

There can be a question when the nexus of "international armed conflicts" was dropped out as of the jurisdictional condition of crimes against humanity. By 1993, the link of "international armed conflicts" withered away from the jurisdiction of crimes against humanity (Note 15). Within this year, the ICTY Statute came into force by the UN Security Council. Therefore, it is revealed that between 1945-1992, it was problematic to apply crimes against humanity outside the situations of an "international armed conflict" according to the customary law requirement. Therefore, the most convincing and acceptable conclusion is made by William Schabas, "the Tadić ruling on crimes against humanity that can take place during peacetime without a nexus of war or aggression moved the law forward dramatically (Schabas, 2006)." From now, it is entirely established that "international armed conflicts" in crimes against humanity as a customary law requirement remained until 1992.

Second, what would be the initial requirement in replacing war nexus in fulfilling the jurisdiction gaps, even in prosecuting crimes against humanity perpetrated in the time of peace. During late 1994, the Legislation of the International Criminal Tribunal for Rwanda (ICTR) was enacted with the description of the defined crimes that left out the link with any types of "armed conflict." Article 3 of the Statute of the ICTR confers that the lists of offenses, namely; murder, extermination, enslavement, rape, etc., can be considered as crimes against humanity, 
"when committed as part of a "widespread or systematic" attack against any civilian population." It is also confirmed as a condition in customary international law in the first significant verdict of the Tadic case in the ICTY (Note 16). Therefore, it is manifested here that the nexus of "international armed conflict" has already been replaced by the elements of "systematic or widespread" attack against any civilian population. The detailed analysis of these two conditions examines below.

\section{Crimes against Humanity in the ICC Law and Jurisprudence}

In the ICC Statute, the customary status of "widespread or systematic" attack as the new requisites of crimes against humanity further emphasizes. Article 7 of the Rome Statute says the attack only needs to be part of a "widespread or systematic" in nature (Note 17). The ICC Statute, having been adopted by 120 States in 1998, signifies the most broadly accepted manifestation of the definition, and it has been elucidated that international agreements had taken away with the armed conflict nexus as the jurisdictional requirement of crimes against humanity (Schabas, 2007). In terms of the modern practice of the ICC, it undeniably true that in most of cases, it links the terms "widespread or systematic" attack against any civilian population to prove the guilt of crimes against humanity.

In the ICC cases, the term "widespread" refers to the attack against a vast quantity of victims or covers a significant geographical area (Prosecutor v Katanga et al. 2008, paras. 394-397). The similar proposition also echoes in scholarly discussion; for example, Werle (2005) mentions that the term "widespread" refers to an attack either takes place in a big geographical area or a tiny geographic region but directed against a vast quantity of unarmed population. Sometimes the ICC refers to the large numbers of victims in standard figures. In the case of Bashir, who was charged with crimes against humanity, the ICC Trial Chamber finds an attack has estimated "widespread," which exaggerated hundreds of thousands of persons and occurred crossways vast swathes of the area (Prosecutor v. Bashir, 2009, para. 84). The term "widespread" further strengthens in some of the ICC cases by articulating that the acts of violence have to be gigantic, regular, carried out jointly with significant gravity that is directed against a group of casualties (Note 18).

Secondly, the word "systematic" pertains to mean the structured types of the attack and the unfeasibility of their accidental happening (Ibid. para. 81). They must characterize as being organized in character and manifesting a prototype in the idea of non-accidental replication of parallel wrongful acts regularly (Prosecutor v. Laurent Gbagbo, 2014, para. 223). The term "systematic" further means the subsistence of a political motive with an accredited strategy or plan following to which the violence is directed, or a philosophy, in the broader sense of the expression, that facilitates the annihilation, persecution, or deteriorating of a group of people (Prosecutor v Blaškić, 2000, para. 203). The acts of violence itself must be widespread or systematic, and not the specific actions through which the perpetrator is charged (Prosecutor v Kordić et al. 2004, para. 94). The sole duty of the Courts and Tribunals is to settle the issues on whether there shall be a limitation or not because "widespread and/or systematic" sometimes tend to go beyond the original nature and scope of such crimes (Schabas, 2016).

Finally, the terms "widespread or systematic" also positively appear in the Statutes of other hybrid and internationalized criminal tribunals (Note 19). So, the prevalent practices of the numerous international judicial bodies, with the recent ICC jurisdiction, prove the customary status of a "widespread or systematic" attack adjacent to an unarmed population as the threshold requirement of crimes against humanity. It is, therefore, time to examine whether the ICTB needs to incorporate a "widespread" or "systematic" attack against any civilian population for the retrospective trial of offenses against humanity.

\section{The Judgment of ICTB: Legal Flaws on Elements of Crimes against Humanity}

To date, the ICTB has settled down all the cases, where individuals were prosecuted for perpetrating crimes against humanity retroactively. In most of the cases, the Tribunal forwards very irrelevant legal reasoning by saying that, "[t]he Act XIX enacted in 1973 which is meant to prosecute crimes against humanity, genocide and system crimes committed in violation of customary international law is ex post facto legislation [which] is literally permitted (Prosecutor v. Mir Quasem Ali, 2013, para. 3)." In many other cases of the ICTB, the exact argument was mentioned without adequately analyzing the legal merit of such retrospective prosecution of crimes against humanity (Note 20). Is it one of the apparent legal errors of the ICTB's material jurisdiction in allowing retroactive prosecution without sufficiently explaining why such proceeding was permitted by the customary international law in 1971 and today? This legal issue of jurisdictional inaccuracy necessitates the following analysis.

\subsection{Missing the Nexus of International Armed Conflict: A Legal Flaw in Customary International Law}

The first requirement that needs to be fulfilled by the ICTB is in 1971 crimes against humanity were conditioned to be committed as one of the most heinous acts in an "international armed conflict" which was enshrined by the 
IMT Nuremberg and established as the customary rule of international law. Concerning this argument, there are two relevant questions step forward.

\subsubsection{Legal Nature of Bangladesh Liberation War}

The legal nature of Bangladesh conflict is one of the vitiating factors in proving the jurisdictional requirement of crimes against humanity in the ICTB. At the same time, the Tribunal deliberately omits it except by merely saying that there was an armed conflict in 1971 (Prosecutor v. Sayeedi, para. 32). Hence three situations need to be examined.

Firstly, none of the ICTB cases clarified whether there was an armed conflict between two independent states or provinces of a federation (Islam, 2019). In the ICTB cases, the liberation conflict was categorized as an "intrastate war," an "internal armed conflict," and an "international armed conflict" without sufficient legal explanation (Note 21). Therefore, it is conferred that the legal nature of the Bangladesh liberation war was never explained by the Tribunal, though it was very crucial in 1971 based on the customary rule of international law to confirm the status of the Bangladesh Liberation War in prosecuting crimes against humanity retroactively. At that time, there were no possibilities to involve in crimes against humanity in a civil war.

Secondly, in the absence of any legal explanation by the ICTB, the factual situations of the Bangladesh Liberation War sufficiently proved that due to the military crackdown of East Pakistanis, the Indian government rapidly advanced its support to East Pakistan during the first phase from the end of March to the end of November 1971 by giving increasing sums of aid and assistance to the Freedom Fighters (International Commission of Jurists, 1972). It was condemned by the international community as a purely internal war, though the killings and the flights of refugees to neighboring India were unfortunate (Onkar, 1979). By its end, however, it was undoubtedly international because India invaded on 3 December 1971 (Akmam, 2002) by a full-fledged military attack against the Pakistani Army in the lands of the then East Pakistan. So, the outcome of the war suddenly changed, and Bangladesh became independent by 16 December. 1971. Therefore, it is enough to contend that there was an interstate armed conflict.

Thirdly, to strengthen the factual circumstances of the 1971 event, it is also indispensable to view international law and jurisprudence. As for interstate armed conflict, Common Article 2 and Additional Protocol I of the Geneva Conventions 1949 refers to "all cases of declared war or of any other armed conflict which may arise between two or more of the High Contracting Parties." A similar legal definition was also advanced by the ICTY Tadic' Appeal Judgment (Note 22), which indisputably justified the Bangladesh Liberation War as an international armed conflict after the direct Indian military intervention. On the contrary, Common Article 3 and Additional Protocol II of the 1949 Geneva Conventions and ICTY jurisprudence have broadly defined an internal armed conflict, "as being circumscribed within the borders of a particular State and being between that State and an organized armed group (Note 23)." However, the Bangladesh conflict is not categorized as this type of armed conflict because the ICTB never clarified whether there was an intrastate armed conflict in 1971 or not. Therefore, it is ascertained here that the Indian direct armed confrontation with the Pakistani Army that was launched on 3 December 1971 legally and factually fulfilled the requirement of an international armed conflict in 1971 between India and Pakistan for the Liberation of Bangladesh (Note 24).

\subsubsection{Possibilities of Committing Crimes against Humanity in the Bangladesh War}

Here, some possible hypotheses need to be examined in establishing the potential linkage between individual criminality, the time, and considerable escalation of committing crimes against humanity.

Firstly, the perpetrated crimes might have been committed in the time of international armed conflict from 3 December to 16 December 1971 in the absence of any precise time frame given by the prosecuting Tribunal. Thus, it is rational to facilitate that when the charges against each individual were counted (after 16 December 1971), the Bangladesh war became international, and the crime might have been committed in connection with it (Robertson, 2015). Nevertheless, the Tribunal never provide any specific time in framing charges of the crimes. For example, in the case of Molla, the Tribunal observed:

"[T] he accused was an active member of Islami Chatra Sangha (ICS) and being in close alliance with Jamat E Islami, actively aided, abetted, facilitated, substantially assisted, and provided moral support and encouragement in committing atrocities in 1971 (Prosecutor v. Abdul Quader Molla, 2013, para.17)," (Note 25).

In this case, the accused was charged with crimes against humanity, whose criminal conduct was not sufficiently mentioned when committed. It might be elucidated that the perpetrated offenses were executed in the international armed conflict phase of the Bangladesh War. The Tribunal further reiterates by saying that "in adjudicating 
culpability of the person accused of criminal acts [in this Tribunal], context and situations prevailing at the relevant time, i.e., the period of the war of liberation in 1971[25 March to 16 December 1971] is to be considered (Prosecutor v. Moulana Abdus Sobhan, 2014, para. 34)." Therefore, it is logically constructed that the perpetrated crimes might have been committed during the phase of international armed conflict of the Bangladesh war (3 December to 16 December 1971). Any crimes against humanity committed during the mentioned time need to be linked with war crimes or crimes of aggression as the jurisdictional requirement of the said crime, which was enshrined by the IMT Nuremberg Charter and Jurisprudence in 1945 and continued throughout 1971. However, the ICTB fails to link between crimes against humanity and war, which lacks a legal competency of the Tribunal in the retroactive prosecution of crimes against humanity.

Secondly, it might be considered, yet in the phase of pre-international war from 25 March to 2 December 1971, an individual's acts amounted as an international crime. The IMT Charter used the expression "before or during the war," which simply means offenses committed before the war also amounted to crimes against humanity. However, the IMT judgment expressly laid down that crimes committed before the outbreak of WW II were not considered as offenses against humanity, analyzes in section 5.1. One of the reasons was during the pre-WW II situation, though crimes were committed, not amount to crimes against humanity due to lack of seriousness and substantial escalation of such heinous crimes. Similarly, the individual acts of the so-called accused of the ICTB were questionable as to reach massive violations of human rights that sufficiently threatened international peace and security in 1971. In the case of Chowdhury, the Tribunal observed:

"[He] actively participated in the horrendous atrocities committed by him in collaboration with Pakistan army and Razakars [local collaborators of the Pakistani Army] on unarmed civilians with intent to destroy in whole or in part of Hindu population as a religious group; thereby he committed offenses of genocide and crimes against humanity (Prosecutor v. Salauddin Quader Chowdhury, 2011, para. 291)."

It was not mentioned by the Tribunal on how an individual's criminal acts were severely violated human rights at a broader scale, even in the civil war time of the Bangladesh Conflict. Therefore, it is again doubtful that the ICTB has any jurisdictional competency in the retroactive prosecution of crimes against humanity.

Finally, it has been logically constructed to support the view that the perpetrated atrocities as the form of heinous offenses were committed in the course of international armed conflict of the Bangladesh event. In 1971, it was not possible to commit crimes against humanity without linking with crimes against peace or war crimes. As a result, it is established beyond any shadow of a doubt that the ICTB did not take account of the issue of international armed conflict as the jurisdictional requirement of crimes against humanity. It was essential to differentiate international crimes from ordinary crimes in indicting the latter one retrospectively.

\subsection{Missing the Elements of Crimes against Humanity in the Contemporary International Law}

One might argue that the ICTB has reemerged in 2010, not in 1973, so the nexus of international armed conflict is not necessary to be proved, as the numerous elemental changes have taken place in the evolution of crimes against humanity. Accordingly, the ICTB needs to abide by the latest development of the law of crimes against humanity, which requires crimes against humanity needs to be perpetrated against any civilian population as the "systematic or widespread" in pattern as blessed by the laws and jurisprudence of the contemporary international courts and tribunals. Once this requirement is fulfilled, the crimes in question could be prosecuted as an ex post facto international crime under retroactive legislation without any limitations. So, the relevant crime could have been perpetrated in interstate or intrastate armed conflict, which was recognized in the recent ICTY Tadić case (Prosecutor v. Tadić 1999, paras. 83-87.

The ICTB omits to prove a correlation with a "systematic or widespread" nature of attacks in justifying the retroactive trial of crimes against humanity. It is reasonable to believe that murder, rape, and arson have not to be promoted into international offenses except any Court or Tribunal establishes an additional component, such as these killings and persecutions were predominantly atrocious and of global concern, since they have perpetrated in connection with a "widespread or systematic" attack against any civilian population (Robertson, 2015). However, in most of the cases, the Tribunal gives an incomplete argument by saying, "[f]rom our discussion ... we have found that all the attacks were systematically made to cause widespread destruction of properties and lives directing against unarmed civilians (Prosecutor v Sayeedi, 2013, par. 246)." Sometimes the Tribunal reasoned that:

"[I]f the specific offenses of 'Crimes against Humanity' which were committed during 1971 are tried under $1973 \mathrm{Act}$; it is obvious that they were committed in the 'context' of the 1971 war of liberation [which] is sufficient to prove the existence of a 'systematic attack' on Bangladeshi self-determined population in 1971 (Prosecutor v. Alim, 2013, para. 118),” (Note 26). 
It is elucidated that once the attack is directed against the defenseless population during the Liberation War of Bangladesh (25 March to 16 December 1971), it automatically fulfills the requirement of the "widespread or systematic" type of attack in categorizing perpetrated acts as crimes against humanity. However, this is not the observation of other international courts and tribunals. The ICC Trial Chamber says, an attack must reach a minimum level of scale before it may amount to crimes against humanity, whether the attack was "widespread or systematic" (Prosecutor v. Jean-Pierre Bemba Gombo, 2009, para. 164). Any type of attack whose seriousness has drawn the attention of international apprehension be considered as crimes against humanity.

Finally, the Tribunal never gives an in-depth legal orientation why it is applying crimes against humanity retroactively and why such crime is different from the usual crime, as the international crimes shall have an extraordinary character. Furthermore, the Tribunal is trying to punish those who acted as collaborators to the Pakistani Army, so their conduct must be proved and differentiated from ordinary crimes beyond any reasonable doubt to ensure jurisdictional competencies.

\section{The Way Forward: An Attempt to Redefine Crimes against Humanity in the ICTB}

From the analysis, it has proved that the Bangladesh Tribunal failed to justify why it is prosecuting crimes against humanity retrospectively? Without legal justification, ex post facto law sometimes facilitates into miscarriage of justice. For example, in a heightened state of affairs, a new regime might ratify retrospective law to indict its rivals capriciously for the past political conduct (Clarke, 2003). It is comparable with the ICTB, where the retroactive prosecution of crimes against humanity can be seen as the arbitrary detention and political persecution by the victor's party. The first arrest phase of the ICTB accused from June to December 2010 suggested a coincidental pattern. Five of the six accused engaged in the top management of Bangladesh's mainly influential Islamic political party, Jamaat E Islami. Jamaat actively opposed independence in 1971, and their alliance with the Bangladesh Nationalist Party (BNP) ensured the current ruling party's defeat at the 1991 and 2001 national election. So, questions arise as to whether the current ruling party-sponsored ICTB, may, after all, have more urgent motives other than trying those accountable for the events of 1971 to face trials (Cammegh, 2011). Therefore, the ICTB is sometimes considered as the real political vendetta (Jalil, 2010).

Another important fact has revealed by the ICTB cases that in the liberation war, many political parties, namely; Pakistan Democratic Party (PDP), Council Muslim League, Muslim League, Nejam E Islami (Prosecutor v. Molla, 2013, para.12), opposed with Jamaat E Islami in collaborating Pakistani Army. However, in practice, more than 20 accused of the ICTB were involved only with the politics of Jamaat. As a result, the current initiative of prosecuting the perpetrators of international offenses committed in the 1971 War operated by the Awami League government is politically motivated without any doubt. Hence, the Bangladesh government needs to revisit the definition of international crimes that are tried before the ICTB. It deposits the neutrality of this Tribunal, which was initiated in 1973, in prosecuting and punishing the authors of heinous crimes perpetrated in the liberation conflict of Bangladesh, if the Bangladesh Tribunal could do the following in adjusting the very meaning of crimes against humanity.

First of all, the ICTB carefully needs to revisit the international Tribunals and Courts' initiative that were existed in the 1970s, in legally adjusting the definition of crimes against humanity to give effect the customary status of the crimes in question. It definitely will prove that Bangladesh is genuinely trying to put an end to long-lasting impunity by reopening the ICTB that was blocked 47 years ago. Therefore, the ICTB needs to add the very nexus of "international armed conflict" as the threshold prerequisite in the definition of crimes against humanity. It will be legally deposited a jurisdictional limit of such offenses since the crimes in question are being prosecuted and punished retroactively after almost half a century later of their commission. The same limitations are also put by the IMT Charter to give the effect of the international character of crimes against humanity.

Secondly, if the ICTB finds it difficult to revisit the old elements of the crimes, then it certainly needs to abide by the recent expansion of international penal law by adding the clause of "widespread or Systematic" attack in the threshold requirement of crimes against humanity. It is the latest jurisdictional requirement of crimes against humanity, which replaced the old law of "armed conflict nexus" and confirmed by the ICTY, ICTR, and ICC statutes. Hence, the ICC jurisdictional requirement of crimes against humanity undoubtedly needs to be incorporated in the ICTB Statute, being Bangladesh as the state party to the Rome Statute, if not, the ICTB does not have any international acknowledgment with a distinctive war crime legislation (Fazi, Tehrani, Ahmed \& Shah, 2019). There is also a rationale available that international criminal law cannot function in a vacuum; so, there is a minimum customary international law requirement that needs to be reflected in prosecuting crimes against humanity retroactively to prove the impartiality of the ICTB. 


\section{Conclusion}

Though the ICTB is named 'the International Crimes Tribunal,' without the engagement of international adjudicators or prosecutors, those have adequately participated in the IMT Nuremberg, ICTY, ICTR, and ICC; the Tribunal remains as an internal judicial process (Mollah, 2019). In any domestic tribunal, the retroactive criminal sanction is regarded as the most unjust form of retrospective law (Edinger, 1995). Hence, the majority State's constitutions and worldwide human rights treaties explicitly ban ex post facto criminal prosecution (Clarke, 2003). Therefore, every Tribunal that is prosecuting crimes against humanity from the Nuremberg up to nowadays faces the same claim from the defense that the prosecution has breached the prohibition on retrospectivity.

However, a constant tension is inevitable between the rule of "nullum crimen sine lege" and the concept of crimes against humanity. The latter is alleged to be a pre-existing international customary norm which absent from any clear treaty definition or authorization, is then used to validate the application of charge of crimes against humanity irrespective of the lack of such an offense in positive local law at the material time (Dubler \& Kalyk, 2018). A similar proposition can be scrutinized in the ICTB, which prosecuting crimes against humanity retroactively that is alleged to be customary international law in 1973, absent from incorporation of any definition of the crimes against humanity either by treaty or existing international law.

Therefore, in prosecuting crimes against humanity retroactively, the ICTB duly needs to take account of the "international armed conflict" nexus, which was a jurisdictional requirement of crimes against humanity in 1971. It was postulated by the IMT Nuremberg and subsequent crystallization of it in the post-Nuremberg periods. If it is not possible for the ICTB to be complied with, then the Tribunal is required to take into account the "widespread or systematic" attack against any civilian population to prove individual guilt of crimes against humanity. Any failure to these, the Tribunal will be considered posing a significant threat to international criminal justice by introducing a dangerous precedent for the future global community.

\section{Acknowledgments}

The author would like to extend his heartfelt gratitude to YAMAGATA Hideo, Professor, and Dean of the Graduate School of International Development, Nagoya University. As an international law scholar, his valuable guidance and insightful comments on the relevant issues facilitated to complete this manuscript efficiently.

\section{References}

Akmam, W. (2002). Atrocities against Humanity during the Liberation War in Bangladesh: A Case of Genocide. Journal of Genocide Research, 4(4), 543-559. https://doi.org/10.1080/146235022000000463

Bassiouni, M. C. (1992). Crimes Against Humanity in International Criminal Law. London: Martinus Nijhoff Publishers.

Bassiouni, M. C. (1999). Ther Nuremberg Legacy: Historical Assessment Fifty Years Later. In B. Cooper (Ed.), War Crimes, the Legacy of Nuremberg (pp. 291-298). New York: TV Books.

Brownlie, I. (1990). Principles of Public International Law (4th ed.). Oxford: Clarendon Press.

Burchard, C. (2006). The Nuremberg Trial and Its Impact on Germany. Journal of International Criminal Justice, 4(4), 800-829. https://doi.org/10.1093/jicj/mq1052

Cammegh, J. (2011, 17 November). In Bangladesh: Reconciliation or Revenge? The New York Times. Retrieved from https://www.nytimes.com/2011/11/18/opinion/in-bangladesh-reconciliation-or-revenge.html

Cassese, A. (2006). Balancing the Prosecution of Crimes against Humanity and Non-Retroactivity of Criminal Law: The Kolk and Kislyiy v. Estonia Case before the ECHR. Journal of International Criminal Justice, 4(2), 410-418.

Clarke, R. (2003). Retrospectivity and the Constitutional Validity of the Bali Bombing and East Timor Trials. Australian Journal of Asian Law, 5(2), 1-32.

Dubler SC, R., \& Kalyk, M. (2018). Crimes against humanity in the $21^{\text {st }}$ Century: Law, Practice and Threats to International Peace and Security. Leiden: Brill | Nijhoff. https://doi.org/10.1163/9789004347687

Edinger, E. (1995). Retrospectivity in Law. University of British Columbia Law Review, 29(5), 5-25.

Fazi, M. A., Tehrani, P. M., Ahmed, M. W., \& Shah, S. A. (2019). Bangladesh's Approach towards International Criminal Law: A Case. Journal of Politics and Law, 12(3), 80-86.

Gallant, K. S. (2009). The Principle of Legality in International and Comparative Criminal Law. Cambridge: Cambridge University Press.

Hirad, A. (2013). Crimes against Humanity and the Armed Conflict Nexus: From Nuremberg to the ICC. European 
Society of International Law Conference Paper Series, 3(1), 1-12. Retrieved from http://www.barhumanrights.org.uk/wp-content/uploads/2015/02/REPORT-ON-THE-INTERNATIONALCRIMES-TRIBUNAL-OF-BANGLADESH.pdf

International Commission of Jurists. (1972). The Events in East Pakistan 1971: A Legal Study. Geneva: International Commission of Jurists.

International Military Tribunal Nuremberg. (The judgment of the International Military Tribunal for the Trial of German Major War Criminals, 30 September and 1 October 1946), reprinted in American Journal of International Law, 41, 172-333.

Islam, M. R. (2019). National Trials of International Crimes in Bangladesh: Transitional Justice as Reflected in Judgments. Leiden: Brill | Nijhoff. https://doi.org/10.1163/9789004389380

Jalil, M. A. (2010). War Crimes Trial in Bangladesh: A Real Political Vendetta. Journal of Politics and Law, 3(2), 110-120.

Jescheck, H. (2004). The General Principles of International Criminal Law Set out in Nuremberg, as Mirrored in the ICC Statute. Journal of International Criminal Justice, 2, 38-55.

Joseph, S., \& Castan, M. (2000). The International Covenant on Civil and Political Rights: Cases, Materials, and Commentary (3rd Ed.). Oxford: Oxford University Press. DOI:10.1093/law/9780199641949.001.0001

Kelsen, H. (1947). Will the Judgment in the Nuremberg Trial Constitute a Precedent in International Law? The International Law Quarterly, 1(2), 153-171.

Linton, S. (2010). Completing the Circle: Accountability for the Crimes of the 1971 Bangladesh War of Liberation. Criminal Law Forum, 21.

Matas, D., \& Charendoff, S. (1987). Justice Delayed: Nazi War Criminals in Canada. Toronto: Summerhill Press.

Menon, P. (2017). International Crimes Tribunal in Bangladesh. MPILux Working Paper 11. Max Planck Institute Luxembourg, 1-19. Retrieved from https://www.mpi.lu/research/working-paper-series/2017/wp-2017-11/

Mettraux, G. (2010). Trial at Nuremberg. In N. Bernaz, \& W. A. Schabas (Eds.), Routledge Handbook of International Criminal Law (pp. 1-17). London: Routledge. https://doi.org/10.4324/9780203836897

Mollah, M. A., H. (2019). War Crimes Trials in Bangladesh: Justice or Politics? Journal of Asian and African Studies. https://doi.org/10.1177/0021909619890117

Onkar, M. (1979). India’s Military Intervention in East Pakistan, 1971-1972. Modern Asian Studies, 13(4), 549580. https://doi.org/10.1017/S0026749X00008465

Popple, J. ( 1989). The Right to Protection from Retroactive Criminal Law. Criminal Law Journal, 13(4), $250-262$.

Prosecutor v. Abdul Quader Molla, Case No. ICT-BD 02 of 2012 (International Crimes Tribunal Bangladesh, Judgment delivered on 5 February 2013).

Prosecutor v. Abul Kalam Azad, Case No. ICT-BD 052012 (International Crimes Tribunal Bangladesh, Judgment delivered on 21 January 2013).

Prosecutor v. Ali Ahsan Muhammad Mujahid, Case No. ICT-BD 04 of 2012 (International Crimes Tribunal Bangladesh, Judgment delivered on 17 July 2013).

Prosecutor v. Blaškić, Case No. IT-95-14-T (International Criminal Tribunal for the former Yugoslavia Trial Chamber Judgment delivered on 3 March 2000).

Prosecutor v. Delowar Hossain Sayeedi, Case No. ICT-BD 01 of 2011 (International Crimes Tribunal Bangladesh, Judgment delivered on 28 February 2013).

Prosecutor v. Elizaphan and Gérard Ntakirutimana, Case No. ICTR-96-10 \& ICTR-96-17-T (International Criminal Tribunal for Rwanda, Judgment and Sentence, 21 February 2003).

Prosecutor v. Jean-Paul Akayesu, Case No. ICTR-96-4-T (International Criminal Tribunal for Rwanda, Judgment, 2 September 1998).

Prosecutor v. Jean-Pierre Bemba Gombo, Case No. ICC-01/05-01/08 (Decision Pursuant to Article 61(7)(a) and (b) of the Rome Statute on the Charges of the Prosecutor by the Pre-trial Chamber-II, International Criminal Court, 15 June 2009).

Prosecutor v. Katanga and Chui, Case No. ICC-01/04-01/07 (Decision on the Confirmation of Charges, International Criminal Court 30 September 2008).

Prosecutor v. Kordić \& Erkez, Case No. IT-95-14/2-A (International Criminal Tribunal for the former Yugoslavia, 
in the Appeals Chamber Judgment on 17 December 17, 2004).

Prosecutor v. Laurent Gbagbo, Case No. ICC-02/11-01/11 (Decision on the confirmation of charges against Laurent Gbagbo, the International Criminal Court, Pre-trial Chamber -I, 12 June 2014).

Prosecutor v. Md. Abdul Alim, Case No. ICT-BD 01 of 2012 (International Crimes Tribunal Bangladesh, Judgment delivered on 9 October 2013).

Prosecutor v. Md. Abdus Sattar, Case No. ICT-BD [ICT-1] 05 of 2018 (International Crimes Tribunal Bangladesh, Judgment delivered on 11 December 2019).

Prosecutor v. Md. Mahidur Rahman \& Md. Afsar Hossain, Case No. ICT-BD [ICT-2] 02 of 2014 (International Crimes Tribunal Bangladesh, Judgment delivered on 20 May 2015).

Prosecutor v. Mir Quasem Ali, Case No. ICT-BD 03 of 2013 (International Crimes Tribunal Bangladesh, Judgment delivered on 2 November 2014).

Prosecutor v. Moslem et al. Case No. ICT-BD [ICT-1] 01 of 2016 (International Crimes Tribunal Bangladesh, Judgment delivered on 19 April 2017).

Prosecutor v. Moulana Abdus Sobhan, Case No. ICT-BD [ICT-2] 01 of 2014 (International Crimes Tribunal Bangladesh, Judgment delivered on 198 February 2015).

Prosecutor v. Muhammad Kamaruzzaman, Case No. ICT-BD (ICT-2) 03 of 2012 (International Crimes Tribunal Bangladesh, Judgment delivered on 9 May 2013).

Prosecutor v. Omar Hassan Ahmad Al Bashir, Case No. ICC-02/05-01/09 (Decision on Warrant of Arrest for Omar Hassan Ahmad Al Bashir, the International Criminal Court, Pre-trial Chamber -I, 4 March 2009).

Prosecutor v. Salauddin Quader Chowdhury, Case No. ICT-BD 02 of 2011 (International Crimes Tribunal Bangladesh, Judgment delivered on 1 October 2013).

Prosecutor v. Salim Jamil Ayyash et al. Case No. STL-11-01/I, (Special Tribunal for Lebanon, Interlocutory Decision on the applicable law: terrorism, conspiracy, homicide, perpetration, cumulative charging on 16 February 2011).

Prosecutor v. Shamsuddin et al. Case No. ICT-BD 01 of 2015 (International Crimes Tribunal Bangladesh, Judgment delivered on 3 May 2016).

Prosecutor v. Syed Md. Qaiser, Case No. ICT-BD [ICT-2] 04 of 2013 (International Crimes Tribunal Bangladesh, Judgment delivered on 23 December 2014).

Prosecutor v. Tadić, Case No. IT-94-1-A, (International Criminal Tribunal for the former Yugoslavia, Opinion and Judgment, 7 May 1997).

Prosecutor v. Tadić, Case No. IT-94-1-A, (International Criminal Tribunal for the former Yugoslavia Decision on The Defence Motion For Interlocutory Appeal on Jurisdiction, 2 October 1995)

Prosecutor v. Tadić, Case No. IT-94-1-A, (International Criminal Tribunal for the former Yugoslavia, Appeal Chamber Judgment, 15 July 1999).

Robertson, QC, G. (2015). Report on the International Crimes Tribunal of Bangladesh. International Forum for Democracy and Human Rights. Retrieved from http://www.barhumanrights.org.uk/wpcontent/uploads/2015/02/REPORT-ON-THE-INTERNATIONAL-CRIMES-TRIBUNAL-OFBANGLADESH.pdf

Robinson, P. H. (2005). Fair Notice and Fair Adjudication: Two Kinds of Legality. University of Pennsylvania Carey Law School, 154, 335-398. Retrieved from https://scholarship.law.upenn.edu/faculty_scholarship/601

Schaack, B. V. (2008). Crimen Sine Lege: Judicial Lawmaking at the Intersection of Law and Morals. Georgetown Law Journal, 97, 1-67. https://ssrn.com/abstract $=1056562$

Schabas, W. A. (2006). The UN International Criminal Tribunals. Cambridge: Cambridge University Press.

Schabas, W. A. (2007). An Introduction to the International Criminal Court (3rd ed.). Cambridge: Cambridge University Press.

Schabas, W. A. (2015). The European Convention on Human Rights: A Commentary. Oxford: Oxford University Press.

Schabas, W. A. (2016). The International Criminal Court: A Commentary on the Rome Statute (2nd ed.). Oxford: Oxford University Press.

Schwelb, E. (1946). Crimes Against Humanity. British Year Book of International Law, 178(23), 205. 
Sen, J. (2012). The Trial of Errors in Bangladesh: The International Crimes (Tribunals) Act and the 1971 War Crime Trial. Harvard Asia Quarterly, 33-43. Retrieved from https://ssrn.com/abstract=2159827

Trials of the Major War Criminals. (Trials of the Major War Criminals Before the International Military Tribunal, Nuremberg, 14 November 1945-1 October 1946) 19, 8-618.

UN Security Council, Report of the Secretary-General Pursuant to Paragraph 2 of Security Council Resolution 808 (1993), UN Doc. S/25704 (3 May 1993), 55.

Valentina, S. (2011). Non-retroactivity of Criminal Law: A New Chapter in the Hissène Habré Saga. Journal of International Criminal Justice, 9(1), 5-23. Retrieved from https://doi.org/10.1093/jicj/mqq081

Werle, G. (2005). Principles of International Criminal Law. The Hague: TMC Asser Press.

Williams, G. (1961). Criminal law, the General Part (2nd ed.). London: Stevens \& Sons Ltd.

\section{Notes}

Note 1. Section 3 (1) of the ICT Act 1973 reads, "[a] Tribunal shall have the power to try and punish any individual or group of individuals ... who commits or has committed [crimes against humanity, genocide, crimes against peace, and war crimes], in the territory of Bangladesh, whether before or after the commencement of this Act."

Note 2. Though there is no clear indication to show that the ICT Act 1973 was enacted to prosecute the perpetrators of 1971 Liberation War only, the jurisprudence of all cases unanimously settled in ICTB spelled out that the ICT Act 1973 was aimed to try and punish those committed heinous crimes in violation of international humanitarian law in the territory of Bangladesh in 1971, during the war of liberation. See, for example- Prosecutor v. Mir Quasem Ali, Case No. ICT-BD 03 of 2013, para. 87; Prosecutor v. Delowar Hossain Sayeedi, Case No. ICT-BD 01 of 2011, para. 53; Prosecutor v. Abdul Quader Molla, Case No. ICT-BD 02 of 2012, para. 98; Prosecutor v. Muhammad Kamaruzzaman, Case No. ICT-BD (ICT-2) 03 of 2012, para 109, para 82; Prosecutor v. Ali Ahsan Muhammad Mujahid, Case No. ICT-BD Case No. 04 of 2012, para. 99.

Note 3. Similar arguments forwarded in the cases of Prosecutor v. Delowar Hossain Sayeedi, Case No. ICT-BD 01 of 2011, para. 52; Prosecutor v. Abdul Quader Molla, Case No. ICT-BD 02 of 2012, para. 3; Prosecutor v. Muhammad Kamaruzzaman, Case No. ICT-BD (ICT-2) 03 of 2012, para.3; Prosecutor v. Salauddin Quader Chowdhury, Case No. ICT-BD 02 of 2011, para. 64; Prosecutor v. Ali Ahsan Muhammad Mujahid, Case No. ICTBD 04 of 2012, para. 3, and Prosecutor v. Professor Golam Azam, Case No. 06 OF 2011, para. 55.

Note 4. Article 35 (1) of the Bangladesh Constitution 1972 says, "[n]o person shall be convicted of any offense except for violation of a law in force at the time of the commission of the act charged as an offense, nor be subjected to a penalty greater than, or different from, that which might have been inflicted under the law in force at the time of the commission of the offense."

Note 5. As Schabas mentions, "[d]elegates from the United States objected to plans to prosecute violations of the 'laws and principles of humanity' that were too uncertain to have any place in a court of criminal justice," [Schabas, W. A. (2015). The European Convention on Human Rights: A Commentary. Oxford: Oxford University Press].

Note 6. Additional Protocol I to the 1949 Geneva Conventions and Relating to the Protection of Victims of International Armed Conflicts (1977), $1125 \quad$ UNTS 3, Art. 75(4)(c). https://reaties.un.org/doc/Publication/UNTS/Volume\%201125/volume-1125-I-17512-English.pdf

Note 7. See, for example, International Covenant on Civil and Political Rights (1976) 999 UNTS 171, Art. 15; European Convention on Human Rights, (1955) 213 UNTS 221, Art. 7; American Convention on Human Rights (1979), 1144 UNTS 123, Art. 9. The rule is also recognized in the Universal Declaration of Human Rights, GA Res. 217A (III), Art. 11(2); African Charter on Human and Peoples' Rights, OAU Doc. CAB/LEG/67/3 Rev. 5, Art. 7(2); Geneva Convention Relative to the Treatment of Prisoners of War, (1950) 75 UNTS 135, Art. 99; Additional Protocol I to the 1949 Geneva Conventions and Relating to the Protection of Victims of International Armed Conflicts (1977), 1125 UNTS 3, Art. 75(4)(c); Additional Protocol II to the 1949 Geneva Conventions and Relating to the Protection of Victims of Non-International Armed Conflicts (1977), 1125 UNTS 609, Art. 6(c).

Note 8. The same reasoning also observed by the Tribunals established under Control Council Law No. 10 in the Allied zones of occupation echoed this certainty: "[t]here is no doubt of the criminality of the acts with which the defendants are charged. They are based on violations of International Law well recognized and existing at the time of their commission." The German High Command Trial, (1949). Law Reports of The Trials of War Criminals, 12,62 . 
Note 9. General Treaty for the Renunciation of War as an Instrument of National Policy, 27 August 1928, 46 Stated. 2343, 94 LNTS 57 [hereinafter "Kellogg-Briand Pact"].

Note 10. Kelsen mentions, "[j]ustice required the punishment of these men, [despite] the fact that under positive law, they were not punishable at the time they performed the acts made punishable with retroactive force. In case two postulates of justice are in conflict ..., the higher one prevails, and to punish those who were morally responsible for the international crime of the [S]econd World War may certainly be considered as more important than to comply with the rather relative rule against ex post facto laws," [Kelsen, H. (1947). Will the Judgment in the Nuremberg Trial Constitute a Precedent in International Law? The International Law Quarterly, 1(2), 165].

Note 11. Affirmation of the Principle of International Law Recognized by the Charter of the Nuremberg Tribunal, UN GA Resolution 95(1), UN GAOR, $1^{\text {st }}$ sess. 55 ${ }^{\text {th }}$ plen. Mtg., UN Doc. A/236 (11 December 1946).

Note 12. International Law Commission, Report on the formulation of Nuremberg principles, prepared by the Special Rapporteur, Mr. J. Spiropoulos, 12 April 1950, reproduced in Yearbook of the International Law Commission,1950,2.https://legal.un.org/docs/?path=../ilc/publications/yearbooks/english/ilc_1950_v2.pdf\&lang $=\mathrm{E}$

Note 13. Article 5 of the ICTY Statute 1993 says, "[t]he International Tribunal shall have the power to prosecute persons responsible for the following crimes when committed in armed conflict, whether international or internal in character, and directed against any civilian population: (a) murder; (b) extermination; (c) enslavement; (d) deportation; (e) imprisonment; (f) torture; (g) rape; (h) persecutions on political, racial and religious grounds; (i) other inhumane acts," UN Sec. Res. 827 (Adopted 25 May 1993).

Note 14. Prosecutor v. Tadić, (IT-94-1-T), Decision on The Defence Motion For Interlocutory Appeal on Jurisdiction, 2 October 1995, para. 141, reads, "[i]t is by now a settled rule of customary international law that crimes against humanity do not require a connection to international armed conflict. Indeed, as the Prosecutor points out, customary international law may not require a connection between crimes against humanity and any conflict at all. Thus, by requiring that crimes against humanity be committed in either internal or international armed conflict, the Security Council may have defined the crime in Article 5 more narrowly than necessary under customary international law. There is no question, however, that the definition of crimes against humanity adopted by the Security Council in Article 5 comports with the principle of nullum crimen sine lege."

Note 15. As Duber and Kalyk correctly mention, "[i]n the period 1945-1992, outside the prosecution of Nazi War Criminals, the proposition that purely internal atrocities [which ]can give rise to either an international criminal jurisdiction or a 'threat to international peace' had little or no support in the state practice of the time," [Dubler SC, R., \& Kalyk, M. (2018). Crimes against humanity in the $21^{\text {st }}$ Century: Law, Practice and Threats to International Peace and Security. Leiden: Brill | Nijhoff, 149].

Note 16. Prosecutor v. Tadić (IT-94-1-T), Opinion and Judgment, 7 May 1997, para. 646 says, "it is now well established that the requirement that the acts be directed against a civilian "population" can be fulfilled if the acts occur on either a widespread basis or in a systematic manner. Either one of these is sufficient to exclude isolated or random acts. The Report of the Secretary-General stipulates that crimes against humanity "refer to inhumane acts of a very serious nature . . committed as part of a widespread or systematic attack against any civilian population." Report of the Secretary-General Pursuant to Paragraph (2) of Security Council Resolution 808 (1993), UN Doc. S/25704 (1993), para. 48.

Note 17. Rome Statute of the International Criminal Court, entered into force 1 July 2002, 2187, UNTS 90 . Art.7 (1) For the purpose of this Statute, 'crime against humanity' means any of the following acts when committed as part of a widespread or systematic attack directed against any civilian population, with knowledge of the attack: (a) Murder; (b) Extermination; (c) Enslavement; (d) Deportation or forcible transfer of population; (e) Imprisonment or other severe deprivation of physical liberty in violation of fundamental rules of international law; (f) Torture, etc.

Note 18. See also in Prosecutor v. Jean-Pierre Bemba Gombo, (ICC-01/05-01/08), Decision Pursuant to Article 61(7)(a) and (b) of the Rome Statute on the Charges of the Prosecutor, 15 June 2009, para. 83; Prosecutor v. Katanga and Chui, (ICC-01/04-01/07), Decision on the Confirmation of the Charges, 30 September 2008, paras 395, 398; Prosecutor v. Jean-Paul Akayesu, (ICTR-96-4-T), Judgment, 2 September 1998, para. 580; Prosecutor v. Elizaphan and Gérard Ntakirutimana, (ICTR-96-10 \& ICTR-96-17-T), Judgment and Sentence, 21 February 2003, para. 804.

Note 19. Available in Sec. 5 of United Nations Transitional Administration in East Timor On the Establishment of Panels with Exclusive Jurisdiction Over Serious Criminal Offences, 6 June. 2000, UN Doc. 
UNTAET/Reg/2000/15; Art. 2. of the Statute of the Special Court for Sierra Leone, 16 January 2002, 2178 UNTS 138, and Art. 5 of the Extraordinary Chambers in the Courts of Cambodia for the Prosecution of Crimes Committed During the Period of Democratic Kampuchea, 27 October 2004.

Note 20. See in the cases of Prosecutor v. Syed Md. Qaiser, Case No. ICT-BD [ICT-2] 04 of 2013, para. 6; Prosecutor v. Moulana Abdus Sobhan, Case No. ICT-BD [ICT-2] 01 of 2014, para. 6; Prosecutor v. Md. Mahidur Rahman \& Md. Afsar Hossain, Case No. ICT-BD [ICT-2] 02 of 2014, para. 4, and Prosecutor v. Md. Abdus Sattar, Case No. ICT-BD [ICT-1] 05 of 2018, para. 6.

Note 21. Articulated in the different judgments of the ICTB. For example, in Prosecutor v. Shamsuddin et al. Case No. ICT-BD 01 of 2015, para. 582 says, "[a]fter the declaration of independence and birth of a separate homeland Bangladesh, the 300 Pakistani occupation armed forces and the armed militia forces formed to collaborate with them started committing [atrocious barbaric] activities directing civilians in the name of fighting the freedom fighters within the territory of Bangladesh and in this way they made them engaged with an 'intra-state war or armed conflict."; In Prosecutor v. Moslem et al. Case No. ICT-BD [ICT-1] 01 of 2016, para. 986 says, "[i]n view of the provisions provided in Section 3(2)(e) of the Act of 1973 violation of any humanitarian rules applicable in armed conflicts laid down in Geneva Conventions of 1949 are crimes within the jurisdiction of this Tribunal. Article 3(1) (a) of the Geneva Convention Relative to the Protection of Civilian Persons in a Time of War of August 1947 prohibits violence to life and persons, the particularly murder of all kinds."; In Prosecutor v. Ali Ahsan Muhammad Mujahid, Case No. ICT-BD [ICT-2] Judgment 2012, para. 140, Prosecutor v Delowar Hossain Sayeedi, Case No. ICT-BD 01 of 2011, para. 39 repeatedly mentioned that the Pakistani Army was an 'occupation army in the territory of Bangladesh.' This expression might be inferred as the indication that the ICTB judges wanted to link that the armed conflict in 1971 was taken place between two independent states, Bangladesh and Pakistan [Islam, M. R. (2019). National Trials of International Crimes in Bangladesh: Transitional Justice as Reflected in Judgments. Leiden: Brill Nijhoff, 121].

Note 22. Prosecutor v. Tadic', Case No. IT-94-1-A, Appeal Judgment, 15 July 1999, para. 84 says, "in case of an internal armed conflict breaking out on the territory of a State, it may become international (or, depending upon the circumstances, be international in character alongside an internal armed conflict) if (i) another State intervenes in that conflict through its troops, or alternatively if (ii) some of the participants in the internal armed conflict act on behalf of that other State."

Note 23. Rome Statute of the International Criminal Court, Art. 8(2)(f), entered into force 1 July. 2002 says, "[i]t (armed conflicts not of an international character) applies to armed conflicts that take place in the territory of a State when there is a protracted armed conflict between governmental authorities and organized armed groups or between such groups."

Note 24. As Linton says, "the Geneva Conventions of 1949, and Hague law in treaty and/or custom, clearly applied from the moment the conflict became internationalized when there was sufficient Indian involvement, which was definitely the case when the Indian forces actively engaged in armed activities in the conflict," [Linton, S. (2010). Completing the Circle: Accountability for the Crimes of the 1971 Bangladesh War of Liberation. Criminal Law Forum, 21, 249].

Note 25. Similar observations also made in other cases regarding the unlimited time of the commission of the offenses, such as in Prosecutor v. Mir Quasem Ali, Case No. ICT-BD 03 of 2013, para 14; Prosecutor v. Delowar Hossain Sayeedi, Case No. ICT-BD 01 of 2011, para 15; Prosecutor v. Muhammad Kamaruzzaman, Case No. ICTBD (ICT-2) 03 of 2012, para 17; Prosecutor v. Ali Ahsan Muhammad Mujahid, Case No. ICT-BD 04 of 2012, para 49.

Note 26. A series of comparable arguments are made in the cases of Prosecutor v. Syed Md. Qaiser, Case No. ICTBD [ICT-2] 04 of 2013, paras. 31, 46; Prosecutor v. Ali Ahsan Muhammad Mujahid, Case No. ICT-BD 04 of 2012, paras. 123, 129, 583; Prosecutor v. Muhammad Kamaruzzaman, Case No. ICT-BD (ICT-2) 03 of 2012, paras. 133, 134.

\section{Copyrights}

Copyright for this article is retained by the author(s), with first publication rights granted to the journal.

This is an open-access article distributed under the terms and conditions of the Creative Commons Attribution license (http://creativecommons.org/licenses/by/4.0/). 